\title{
Soil Organic Carbon Stocks in Deep Soils at a Watershed Scale on the Chinese Loess Plateau
}

\author{
Yunqiang Wang* \\ State Key Lab. of Loess and Quaternary \\ Geology \\ Institute of Earth Environment \\ Chinese Academy of Sciences \\ Xi'an, Shaanxi 710061 \\ China

\section{Xiangwei Han} \\ Key Lab. of Ecosystem Network \\ Observation and Modeling \\ Institute of Geographic Sciences and \\ Natural Resources Research \\ Chinese Academy of Sciences \\ Beijing 100101 \\ China

\section{Zhao Jin} \\ State Key Lab. of Loess and Quaternary \\ Geology \\ Institute of Earth Environment \\ Chinese Academy of Sciences \\ Xi'an, Shaanxi 710061 \\ China
}

\section{Chencheng Zhang}

Linchuan Fang

State Key Lab. of Soil Erosion and

Dryland Farming on the Loess Plateau

Institute of Soil and Water Conservation

Northwest A\&F Univ.

Yangling 712100

China

\section{Core Ideas:}

- SOC stocks under three land uses were measured to a soil depth of $500 \mathrm{~cm}$.

- SOC stocks in the $0-200 \mathrm{~cm}$ soil layer were significantly the lowest under shrubland.

- Significantly higher SOC stocks occurred in the loamy than in the sandy soils.

- Land use, soil texture, and water significantly affected SOC stock to depths of $500 \mathrm{~cm}$.

- A considerable amount of SOC is stored in deep soils on the Chinese Loess Plateau.
An accurate evaluation of soil organic C (SOC) stocks is important to C management and to understanding fully the role of soils in the $\mathrm{C}$ cycle. However, SOC stocks in deep soils and the factors that affect them have been largely ignored. We measured SOC stocks and other soil properties to a depth of $500 \mathrm{~cm}(n=73)$ under three land uses in the Lao Ye Man Qu watershed on the Chinese Loess Plateau. Similar patterns in the vertical distributions of SOC stocks were found under cropland, grassland, and shrubland. However, for the 0 - to $200-\mathrm{cm}$ soil layer, SOC stocks were significantly lower under shrubland than under either cropland or grassland. The SOC stocks under cropland, grassland, and shrubland in the 0 - to $100-\mathrm{cm}$ layer were $2.64 \pm$ $0.67,2.50 \pm 0.69$, and $1.99 \pm 0.22 \mathrm{~kg} \mathrm{~m}^{-2}$, respectively; in the 0 - to $500-\mathrm{cm}$ layer they were $8.34 \pm 2.26,8.37 \pm 2.01$, and $7.26 \pm 1.00 \mathrm{~kg} \mathrm{~m}^{-2}$, respectively. Significantly higher SOC stocks occurred in loamy than sandy soils $(\boldsymbol{P}<$ 0.01 ), and they were lower at the mid than at the upper and lower slope positions. However, SOC stocks were similar in sunlit and shaded soils. Pearson correlation analysis indicated that land use, soil texture, and soil water content significantly affected SOC stocks in each $100-\mathrm{cm}$ soil layer to a depth of $500 \mathrm{~cm}$. Effects of topographic features and $\mathrm{pH}$ varied with increasing depth. A considerable amount of SOC was stored in deep soils, indicating the SOC content dependence on time and depth. This information is essential for evaluating $C$ fluxes, estimating $C$ stocks, and for managing the $C$ cycles in regions around the world with deep soils.

Abbreviations: CLP, Chinese Loess Plateau; OC, organic carbon; SOC, soil organic carbon; SWC, soil water content.

S oil is the largest pool of organic $\mathrm{C}(\mathrm{OC})$ in terrestrial ecosystems and contains more $\mathrm{C}$ than the plant biomass and the atmosphere combined (Fontaine et al., 2007; Lal, 2004a). Soil can function as either a sink or a source of atmospheric $\mathrm{CO}_{2}$. This function depends on the dynamic equilibrium between the $\mathrm{C}$ inputs ( $\mathrm{C}$ uptake), which involve incorporated plant-derived organic material and turnover rates, and $\mathrm{C}$ outputs (C release), which are due to decomposition (Davidson et al., 2011; Davidson and Janssens, 2006; Tian et al., 2011). Small changes in the content of soil OC (SOC) caused by alterations in land use and soil management practices or in soil erosion rates at regional to global scales could significantly impact atmospheric $\mathrm{CO}_{2}$ concentrations (Díaz-Hernández, 2010; Jeong et al., 2013; Lal et al., 2007) and thereby affect local and global climate conditions (Desjardins et al., 2005; Lal, 2004b). A better understanding of the magnitude, spatial distributions and variations, and the control of OC in soil is necessary for evaluating the main biogeochemical processes and feedbacks involving soil-atmosphere $\mathrm{CO}_{2}$ exchange (Hergoualc'h and Verchot, 2011; Wang et al., 2010b).

Considerable interest has recently been generated by the assessment of spatial distributions and variations in SOC concentrations and stocks in various ecosys-

Soil Sci. Soc. Am. J. 80:157-167

doi:10.2136/sssaj2015.06.0220

Received 9 June 2015.

Accepted 28 Sep. 2015.

*Corresponding author (wangyq@ieecas.cn; wangyunq04@163.com).

(C) Soil Science Society of America, 5585 Guilford Rd., Madison WI 53711 USA. All Rights reserved. 
tems at site, local, slope, watershed, regional, continental, and global scales (Burnham and Sletten, 2010; Han et al., 2010; Hou et al., 2012; Huo et al., 2013; Jimenez et al., 2008; Lal, 2004b; Liu et al., 2011; Tornquist et al., 2009; Van Minnen et al., 2009; Wang et al., 2003, 2010a). These studies have enriched the understanding of the patterns and control of SOC distributions at these scales. Most of these studies have focused on SOC in the upper 0 - to $100-\mathrm{cm}$ soil layer, which generally stores most of the SOC (Shi et al., 2013). However, the accumulation of SOC in deeper soil layers (below $100 \mathrm{~cm}$ ) can contribute substantially to $\mathrm{C}$ sequestration. More than two-thirds of annual plant production can be allocated to belowground structures that ultimately become incorporated into the soil (Liebig et al., 2005).

The amount of SOC stock in regions with deep soils depends greatly on soil depth (Harrison et al., 2011). Nepstad et al. (1994) found that an Amazonian forest soil deeper than 100 $\mathrm{cm}$ contained more $\mathrm{C}$ than the aboveground biomass, and as much as $15 \%$ of this deep SOC turned over on annual or decadal timescales. Batjes (1996) reported a 60\% increase in the global SOC budget when data for the 100- to 200-cm soil layer were included. Jobbágy and Jackson (2000) reported that the global SOC stock increased by $33 \%$ when SOC data for the 100 - to $200-\mathrm{cm}$ soil layer was included with those for the 0 - to $100-\mathrm{cm}$ layer and increased by a further $23 \%$ when the $200-$ to $300-\mathrm{cm}$ layer was included. Interest has since been generated in exploring SOC contents in deeper soils, such as those at depths of 600 cm (Sommer et al., 2000), $1100 \mathrm{~cm}$ (Davidson et al., 2011), and $3800 \mathrm{~cm}$ (Harper and Tibbett, 2013). These studies have suggested that SOC in deeper soil layers must be included when estimating the true soil $\mathrm{C}$ pool at various spatial scales. Stored SOC in the 100- to 600-cm soil layer in eastern Amazonia contributed about $50 \%$ of the SOC stored in the 0 - to $600-\mathrm{cm}$ layer, although the SOC content in the deeper layers (below $100 \mathrm{~cm}$ ) was lower than that in the upper 100-cm layer (Sommer et al., 2000). Rumpel and Kögel-Knabner (2011) recently summarized the relative contributions of soil layers to SOC pools and the sources, composition, and mechanisms of stabilization and destabilization of SOC stored in deep soil layers. These studies of SOC in very deep soils further support the necessity of ascertaining deep SOC stocks and the factors that may influence them.

The soils of the Chinese Loess Plateau (CLP) have formed over deep loessial-paleosol deposits and are associated with a unique landscape that has been cultivated for thousands of years and has been severely eroded (Chen et al., 2007b; Lu et al., 2012). The losses of soil and water in the region are susceptible to changes in land use and/or climate and in the past have generally reduced agricultural productivity and concentrations of SOC (Chen et al., 2007b). Liu et al. (2011) determined the mean SOC stocks in the 0 - to $20-\mathrm{cm}\left(2.64 \mathrm{~kg} \mathrm{~m}^{-2}\right)$ and 0 - to $100-\mathrm{cm}\left(7.70 \mathrm{~kg} \mathrm{~m}^{-2}\right)$ soil layers on the CLP, which were less than those reported $\left(5.45-8.0 \mathrm{~kg} \mathrm{~m}^{-2}\right)$ for the same depths in other regions of China (Wu et al., 2003).

The Chinese government has implemented various programs since the early 1990 s to control soil erosion and to restore an ecologically sustainable environment on the CLP (Chen et al., 2007b). The cover of vegetation has thus been increasing across the CLP, and slopes have been stabilized by banning cultivation at inappropriate sites while establishing grassland and forests using perennial plants (Chen et al., 2007b; Wang et al., 2015). Some of these perennial species can extend their root systems to extract water and nutrients from deep soils. For example, the roots of alfalfa (Medicago sativa L.), Korshinsk peashrub (Caragana korshinskii Kom.), and southern Chinese pine (Pinus tabuliformis Carrière) can reach depths of 15.5, 22.4, and 21.5 $\mathrm{m}$, respectively (Wang et al., 2009b). These recently established systems of deep roots can alter the cycling of water and of $\mathrm{C}$ and other nutrients (Wang et al., 2013). The ongoing widespread planting of perennial species on the CLP increases the importance of investigating the vertical distribution of SOC in deep soil layers and of identifying the causes of any differences that might be observed.

The distribution and magnitude of SOC in deep soils are the result of a number of physical, chemical, and biological processes as well as their interactions at a wide range of time scales. These processes are influenced by climatic factors (e.g., precipitation and temperature), soil properties (e.g., texture and structure), topography (e.g., altitude and slope aspect), land use (e.g., cropland, grassland, and shrubland), plant characteristics (e.g., vegetation coverage, age, and root system), and related ecological (e.g., organic-debris supplementation), biological (e.g., decomposition), and hydrological (e.g., erosion) processes (Booker et al., 2013; Dou et al., 2013; Liu et al., 2011; Nepstad et al., 1994; Wang et al., 2014a; Wiesmeier et al., 2012). Of these factors, land use is perhaps the most readily controlled by humans (Chen et al., 2007a; Dilling and Failey, 2013; Lu et al., 2012). Evaluating the influence of land use on deep SOC is thus essential to land use management and planning and to sustainable management of soil C.

A better understanding of the amount of deep SOC stock and its influencing factors (e.g., land use and topography) is essential for assessing the impacts of ecological restoration projects on soil $\mathrm{C}$ cycles. The accuracy of model prediction, the regulation of climate, and changes in land cover depend on a clear understanding of the SOC distributions in multiple soil layers. Therefore, our objectives in this study were to: (i) estimate SOC stocks to a depth of $500 \mathrm{~cm}$ under different land uses, topographies, and soil textures at a watershed scale in the wind-water erosion crisscross region of the CLP; and (ii) evaluate the factors contributing to SOC stocks at different depths.

\section{MATERIALS AND METHODS}

\section{Study Area}

The study was conducted in the Lao Ye Man Qu watershed, $14 \mathrm{~km}$ west of Shenmu County, Shaanxi Province, China (Fig. 1). The watershed covers an area of 20 ha and is characterized by a temperate semiarid climate. The mean annual temperature is $8.4^{\circ} \mathrm{C}$ (lowest and highest monthly temperatures are -9.7 and $23.7^{\circ} \mathrm{C}$ in January and July, respectively). Precipitation var- 


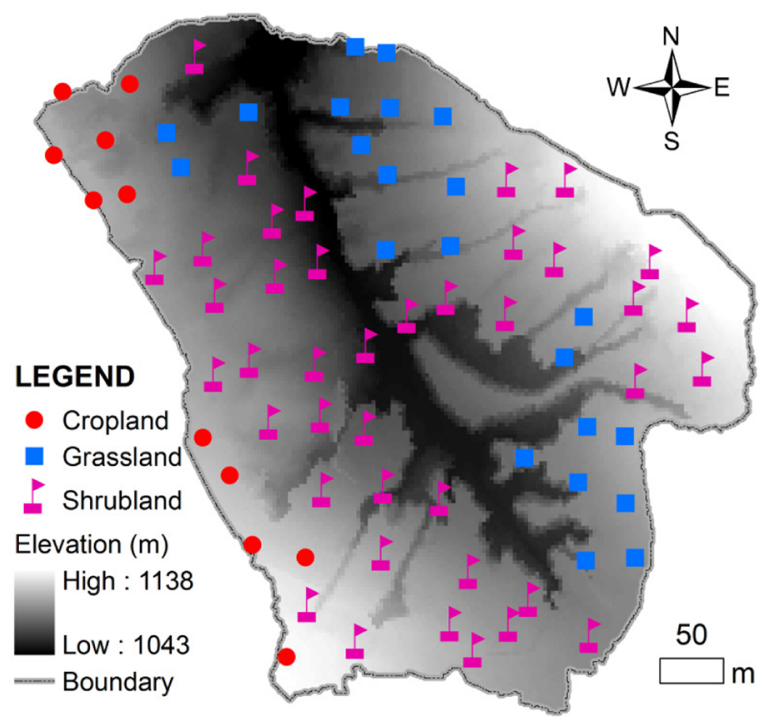

Fig. 1. Distribution of soil sampling points $(n=73)$ under different land uses within the Lao Ye Man Qu watershed that has a gully system that can be identified by elevation changes denoted by the gray scale. The scale unit is $50 \mathrm{~m}$.

ies annually from 108.6 to $819.1 \mathrm{~mm}$, with a mean annual precipitation of $437.4 \mathrm{~mm}, 70$ to $80 \%$ of which falls from June to September. The mean annual wind speed is $2.2 \mathrm{~m} \mathrm{~s}^{-1}$.

This area is typical of the "wind-water erosion crisscross region" of the CLP. In the rainy season, frequent rainstorms and/ or flooding may cause severe soil erosion by water. In the dry season, high winds and low water contents in the surface soil can result in high levels of wind erosion. The ecosystem of the area is fragile. The natural vegetation is dominated by degenerating semiarid grassland species. The types of land use in the watershed are mainly cropland (potato [Solanum tuberosum L. or bean [Phaseolis vulgaris L.), grassland (perennial grasses and legumes, dominated by Stipa bungeana Trinius), and shrubland (covered mostly by Korshinsk peashrub, with sporadically distributed poplar [Populus spp.] and apricot [Prunus spp.] trees). The altitude, slope gradient, and vegetation for the three land uses are reported in Table 1.

\section{Soil Sampling and Chemical Analysis}

Soil samples were collected from the centers of 50 - by $50-\mathrm{m}$ grid units, the locations of which were established by a portable GPS receiver. Some sampling points within certain grid units

Table 1. Summary statistics of environmental variables for three land uses in the Lao Ye Man Qu watershed.

\begin{tabular}{|c|c|c|c|c|c|c|c|}
\hline Var & $n$ & Min. & Max. & Mean & SD & Skewness & Kurtosis \\
\hline & \multicolumn{7}{|c|}{ Cropland (soybean, potato) } \\
\hline Altitu & 11 & 1211.0 & 1251.0 & 1227.3 & 11.7 & 0.498 & 0.292 \\
\hline \multirow[t]{2}{*}{ Slope gradient, ${ }^{\circ}$} & 11 & 2 & 25 & & & & \\
\hline & \multicolumn{7}{|c|}{ Grassland (Stipa bungeana, alfalfa) } \\
\hline Altitude, $\mathrm{m}$ & 22 & 1188.0 & 1228.0 & 1211.0 & 10.3 & -0.402 & -0.262 \\
\hline \multirow[t]{2}{*}{ Slope gradient, ${ }^{\circ}$} & 22 & 6 & 21 & 12.0 & 3.8 & 0.331 & 0.132 \\
\hline & \multicolumn{7}{|c|}{ Shrubland (almond, Caragana korshinskii) } \\
\hline Altitude, $\mathrm{m}$ & 40 & 1178.0 & 1253.0 & 1216.7 & 18.4 & 0.046 & -0.467 \\
\hline Slope gradient, ${ }^{\circ}$ & 40 & 5 & 36 & 14.4 & 7.1 & 1.469 & 1.921 \\
\hline
\end{tabular}

were inaccessible, such as those in deep erosion gullies. However, the remaining 73 sites in the watershed were investigated (Fig. 1). A total of 584 soil samples were collected using a soil auger $(5$ $\mathrm{cm}$ in diameter) from eight layers: 0 to 10,10 to 20,20 to 60,60 to 100,100 to 200,200 to 300,300 to 400 , and 400 to $500 \mathrm{~cm}$.

Gravimetric soil water content (SWC) (\% w/w) was determined from the loss of mass during oven drying at $105^{\circ} \mathrm{C}$ to constant mass. Other subsamples were air dried and analyzed after passing through either a $1.0-\mathrm{mm}$ (for texture and $\mathrm{pH}$ ) or, following grinding, a $0.25-\mathrm{mm}$ (for SOC content) mesh; note that the 1.0- to $2.0-\mathrm{mm}$ fraction of soils on the CLP is generally negligible (Liu et al., 2011). Soil texture was determined by laser diffraction using a Mastersizer2000 (Malvern Instruments), and soil $\mathrm{pH}\left(1: 5\right.$ in $\left.\mathrm{H}_{2} \mathrm{O}\right)$ was determined using a $\mathrm{pH}$ meter with a glass electrode (McLean, 1982). The SOC content was measured using the Walkley-Black method (Nelson and Sommers, 1982).

\section{Calculation of Soil Organic Carbon Stock}

Total amounts of SOC were calculated from the mass fractions of SOC determined for the individual samples for a soil column of unit area by using bulk density (BD) data and the thickness of the sampled soil layer. The sampling and measurement of $\mathrm{BD}$ is labor intensive, costly, and often impractical, especially at depths below $1 \mathrm{~m}$. Therefore, we used BD values derived from a pedotransfer function (PTF) developed from 1254 measured data sets from the CLP region (Wang et al., 2014b). For soils on the CLP, this PTF outperformed other established PTFs, such as those presented by Alexander (1980), Manrique and Jones (1991), and Balland et al. (2008). The PTF model used was

$$
\begin{aligned}
\mathrm{BD}= & 1.8284+0.0429 \times \log _{10} \text { Clay } \\
& +0.0205 \times \text { Clay }^{0.5}-0.0125 \times \cos \text { Clay } \\
& -0.0061 \times \text { Silt }+0.0001 \times \text { Silt } \times \text { SG } \\
& -0.0098 \times \text { SG }-0.0071 \times \text { SOC } \\
& -0.0505 \times \text { SOC }^{0.5}+0.0002 \times \text { SOC }^{2}
\end{aligned}
$$

where SG is the slope gradient $\left({ }^{\circ}\right)$. This equation had been derived from data collected from depths within 0 - to $40-\mathrm{cm}$ soil layers, so additional data were collected (BD, SG, and contents of SOC, clay, and silt) from two sites at depths of 520 and $510 \mathrm{~cm}$ to evaluate its accuracy. The coefficient of determination, the root mean square error, and the mean residual error were $0.5940,0.1455$, and -0.1062 , respectively, indicating that this equation was acceptable for predicting $\mathrm{BD}$ for deep layers. As far as can be determined, a better equation for predicting $\mathrm{BD}$ in deep layers on the CLP has not been developed, and equations developed for other regions performed more poorly than Eq. [1].

The SOC stock, i.e., C mass per unit area of a soil layer, was calculated according to Grimm et al. (2008) as

SOC stock $=\mathrm{SOC} \times \mathrm{BD}\left(1-F_{\text {content }}\right) \Delta d \times \mathrm{UFC} \quad$ [2] 
where SOC stock is the SOC storage $\left(\mathrm{kg} \mathrm{m}^{-2}\right), \mathrm{SOC}$ is the SOC concentration $\left(\mathrm{g} \mathrm{kg}^{-1}\right), \mathrm{BD}$ is the soil bulk density $\left(\mathrm{g} \mathrm{cm}^{-3}\right)$, $F_{\text {content }}$ is the proportion of non-soil particles $>2 \mathrm{~mm}$ in diameter (dimensionless), $\Delta d$ is the thickness of the soil layer $(\mathrm{cm})$, and UFC is a unit conversion factor that has a value of 0.01 . The occurrence of coarse fragments in the loessial soils of the CLP is rare, so $F_{\text {content }}$ can be considered to be negligible (Liu et al., 2011). The fine texture of the quaternary loessial deposits on the CLP is due to their transportation by wind and subsequent deposition from an arid source area. The $\mathrm{C}$ mass per unit area to a given soil depth was calculated as the total of the $\mathrm{SOC}_{\text {storage }}$ amounts of all of the layers within that depth.

\section{Data Analysis}

Basic statistical parameters, including minimum, maximum, mean, and standard deviation, were calculated. The normality of the data distributions was also assessed using estimates of skewness and kurtosis. The soil texture of all soil profiles was classified based on the relative proportions of clay, silt, and sand using the textural triangle. The soil profiles under the various land uses were characterized at a watershed scale by their basic soil properties including SWC, texture, and $\mathrm{pH}$ to a depth of $500 \mathrm{~cm}$. An analysis of variance (ANOVA) and post hoc least significant difference test were used to evaluate the differences in SOC stocks among the land use types, soil classes, and topographical properties, both for the entire soil profile and for the various layers comprising it.

Pearson correlation coefficients were calculated to determine the strength of correlations between SOC stocks and the various soil and environmental variables under investigation. To further evaluate the relationship between SOC stock and land use type, typical ordinal categorical variables were used. A numeric code was assigned to each of the three land use types. The codes corresponded to the order of the mean values of the land use SOC stock. The SOC stock for each type of land use was found to follow the order: shrubland < grassland $<$ cropland. Therefore, the land use was represented by three ordinal numerically coded variables: 1 = shrubland; 2 = grassland; and $3=$ cropland.

To simplify the statistical analysis and to avoid confounding influences, the SOC stocks were divided by soil type (i.e., sandy or loamy soil). To better evaluate the impact of land use on SOC stocks and avoid the influence of soil type, only data from the 60 sites with loamy soils were used to conduct the one-way ANOVA; i.e., the other 13 sites with sandy soils were excluded from the analysis. The ANOVA was then used to further evaluate the effects of slope aspect (either shaded or sunlit) and slope position (i.e., upper, mid, and lower slope) as indicators of topographical effects on SOC stocks.

All statistical analyses were performed using Microsoft Excel 2010, SPSS Version 13.0, or SigmaPlot Version 12.0. The map of the sampling sites was generated by GIS software (ESRI ArcMap 9.3).

\section{RESULTS \\ Soils Characteristics in the 0 - to $500-\mathrm{cm}$ Profile}

Soil texture was comparable under cropland and grassland in all soil layers, with similar mean soil fraction contents (sand: 34.1 and 26.5\%; silt: 54.0 and 60.8\%; clay: 11.9 and $12.7 \%$ for cropland and grassland, respectively) (Table 2). Shrubland sites had a higher mean sand content (45.6\%) and lower proportions of clay $(9.8 \%)$ and silt (44.7\%). The sand contents decreased gradually with depth, whereas silt contents increased. Mean SWC decreased in the order: cropland > grassland > shrubland, with significant differences between shrubland and either cropland or grassland $(P<0.01)$. Soil $\mathrm{pH}$ ranged from 9.0 to 9.2 for the three land uses, but differences were not significant $(P>$ 0.20 ), indicating a high degree of homogeneity in soil acidity in both the vertical and horizontal directions at the watershed scale.

Two soil classes were identified in the watershed (Table 3 ). Loamy soil $(n=60)$ and sandy soil $(n=13)$ accounted for 82 and $18 \%$ of the 73 sampled sites, respectively. Both cropland and grassland sites all had loamy soils, whereas $68 \%$ of the shrubland sites had loamy soils $(n=27)$ and $32 \%$ had sandy soils $(n=13)$. The vertical distributions of particles in the loamy and sandy soils in the shrubland also indicated a different pattern of soil texture in this land use (Fig. 2). Deep soil contained more clay, especially at sites with a sandy surface soil. However, deep soil layers were relatively sandier at sandy soil sites than at loamy soil sites.

The mean SOC concentration of the entire watershed in the 0 - to 500 -cm profile was $1.40 \pm 1.12 \mathrm{~g} \mathrm{~kg}^{-1}$. Ranges of mean SOC concentrations to a depth of $500 \mathrm{~cm}$ under the three land types were $0.84 \pm 0.20$ to $4.69 \pm 1.22 \mathrm{~g} \mathrm{~kg}^{-1}$ (cropland), $0.95 \pm$ 0.19 to $4.08 \pm 1.22 \mathrm{~g} \mathrm{~kg}^{-1}$ (grassland) and $0.80 \pm 0.24$ to 2.87 $\pm 1.36 \mathrm{~g} \mathrm{~kg}^{-1}$ (shrubland), which demonstrates a high degree of variability (Table 2). Concentrations of SOC were the highest and most variable in the surface layers under all land uses. The SOC concentrations in the top 100-cm soil layer decreased rapidly with soil depth to about $1.00 \mathrm{~g} \mathrm{~kg}^{-1}$; below $100 \mathrm{~cm}$, decreases were relatively slow. Concentrations of SOC down the entire soil profile were lower under shrubland than under either cropland or grassland. The SOC concentrations in the top 20-cm layer were marginally, but not significantly, higher under cropland than under grassland. The grassland generally had higher SOC concentrations than the cropland in the deeper soil layers.

\section{Soil Organic Carbon Stocks for Different Soil Types, Land Uses, and Topography \\ Soil Type}

The SOC stocks were significantly higher in the loamy than in the sandy soils in each layer within the 0 - to $500-\mathrm{cm}$ soil profile (Fig. 3). In the sandy soils, the ratios of the SOC stocks in the 100- to 200-, 200- to 300-, 300- to 400-, and 400- to 500-cm layers to those in the 0 - to $100-\mathrm{cm}$ layer were $0.65,0.76,0.87$, and 0.88 , respectively; in the loamy soils, these ratios were 0.64 , $0.60,0.60$, and 0.59 . This implies that the total amount of stored SOC was greater in the loamy soils than in the sandy soils. In ad- 
Table 2. Basic properties of soils under three land uses in the Lao Ye Man Qu watershed.

\begin{tabular}{|c|c|c|c|c|c|c|}
\hline Soil depth & Soil water content & Clay & Silt & Sand & $\mathrm{pH}$ & Soil organic C \\
\hline $\mathrm{cm}$ & & & - & - & & $\mathrm{g} \mathrm{kg}^{-1}$ \\
\hline & \multicolumn{4}{|c|}{ Cropland $(n=11)$} & & \\
\hline 0-10 & $9.0 \pm 2.5+$ & $9.7 \pm 2.7$ & $43.6 \pm 12.2$ & $46.7 \pm 14.8$ & $9.0 \pm 0.3$ & $4.69 \pm 1.22$ \\
\hline 10-20 & $8.9 \pm 3.0$ & $11.4 \pm 3.9$ & $54.3 \pm 16.0$ & $34.3 \pm 19.6$ & $9.0 \pm 0.3$ & $2.84 \pm 1.04$ \\
\hline $20-60$ & $9.2 \pm 2.4$ & $11.7 \pm 3.6$ & $55.3 \pm 17.0$ & $33.1 \pm 20.2$ & $9.0 \pm 0.3$ & $1.38 \pm 0.33$ \\
\hline 60-100 & $10.0 \pm 2.5$ & $13.6 \pm 3.3$ & $60.6 \pm 9.4$ & $25.8 \pm 11.7$ & $9.0 \pm 0.3$ & $1.16 \pm 0.29$ \\
\hline 100-200 & $8.5 \pm 3.7$ & $12.1 \pm 4.9$ & $55.2 \pm 16.4$ & $32.7 \pm 20.4$ & $9.0 \pm 0.3$ & $1.09 \pm 0.49$ \\
\hline 200-300 & $8.2 \pm 3.6$ & $13.1 \pm 3.9$ & $58.3 \pm 13.6$ & $28.6 \pm 16.6$ & $9.0 \pm 0.3$ & $0.93 \pm 0.21$ \\
\hline $300-400$ & $7.8 \pm 3.2$ & $12.5 \pm 4.2$ & $55.3 \pm 14.4$ & $32.1 \pm 17.9$ & $9.0 \pm 0.3$ & $0.88 \pm 0.20$ \\
\hline $400-500$ & $7.7 \pm 3.3$ & $11.4 \pm 5.2$ & $\begin{array}{c}49.4 \pm 19.8 \\
\text { Grassland }(n=22)\end{array}$ & $39.2 \pm 24.3$ & $9.0 \pm 0.3$ & $0.84 \pm 0.20$ \\
\hline $0-10$ & $6.3 \pm 3.0$ & $10.8 \pm 2.8$ & $54.4 \pm 9.2$ & $34.8 \pm 11.7$ & $9.2 \pm 0.1$ & $4.08 \pm 1.22$ \\
\hline 10-20 & $7.5 \pm 3.3$ & $12.3 \pm 3.4$ & $59.4 \pm 11.4$ & $28.4 \pm 14.3$ & $9.2 \pm 0.1$ & $2.62 \pm 0.72$ \\
\hline $20-60$ & $10.1 \pm 3.5$ & $13.5 \pm 4.5$ & $61.8 \pm 13.2$ & $24.7 \pm 17.2$ & $9.2 \pm 0.1$ & $1.41 \pm 0.40$ \\
\hline $60-100$ & $11.0 \pm 2.5$ & $13.4 \pm 3.5$ & $61.4 \pm 9.4$ & $25.1 \pm 11.9$ & $9.2 \pm 0.1$ & $1.12 \pm 0.33$ \\
\hline 100-200 & $9.0 \pm 2.6$ & $13.4 \pm 3.0$ & $63.1 \pm 8.5$ & $23.5 \pm 10.7$ & $9.2 \pm 0.1$ & $1.03 \pm 0.29$ \\
\hline 200-300 & $8.1 \pm 2.8$ & $12.4 \pm 3.0$ & $61.3 \pm 11.7$ & $26.3 \pm 14.1$ & $9.2 \pm 0.1$ & $0.95 \pm 0.23$ \\
\hline $300-400$ & $8.3 \pm 3.0$ & $12.5 \pm 2.9$ & $61.5 \pm 8.8$ & $26.0 \pm 11.1$ & $9.2 \pm 0.1$ & $0.98 \pm 0.20$ \\
\hline $400-500$ & $8.3 \pm 3.2$ & $12.9 \pm 2.5$ & $\begin{array}{c}63.8 \pm 9.4 \\
\text { Shrubland }(n=40)\end{array}$ & $23.3 \pm 11.4$ & $9.2 \pm 0.1$ & $0.95 \pm 0.19$ \\
\hline $0-10$ & $5.1 \pm 2.2$ & $6.7 \pm 4.5$ & $35.8 \pm 21.6$ & $57.5 \pm 25.9$ & $9.0 \pm 0.8$ & $2.87 \pm 1.36$ \\
\hline 10-20 & $5.9 \pm 3.3$ & $7.6 \pm 5.0$ & $37.9 \pm 23.2$ & $54.5 \pm 28.0$ & $9.0 \pm 0.6$ & $1.67 \pm 0.69$ \\
\hline $20-60$ & $6.7 \pm 3.6$ & $8.8 \pm 5.6$ & $39.9 \pm 24.1$ & $51.3 \pm 29.4$ & $9.0 \pm 0.6$ & $0.94 \pm 0.42$ \\
\hline $60-100$ & $7.1 \pm 3.7$ & $9.7 \pm 5.9$ & $42.6 \pm 24.9$ & $47.7 \pm 30.4$ & $9.0 \pm 0.6$ & $0.77 \pm 0.30$ \\
\hline 100-200 & $6.8 \pm 3.5$ & $10.0 \pm 5.1$ & $45.9 \pm 23.6$ & $44.0 \pm 28.4$ & $9.1 \pm 0.5$ & $0.75 \pm 0.29$ \\
\hline 200-300 & $6.7 \pm 3.6$ & $11.4 \pm 5.3$ & $50.4 \pm 21.4$ & $38.2 \pm 26.2$ & $9.0 \pm 0.5$ & $0.77 \pm 0.23$ \\
\hline $300-400$ & $7.0 \pm 3.7$ & $11.2 \pm 4.6$ & $49.7 \pm 18.4$ & $39.1 \pm 22.1$ & $9.0 \pm 0.6$ & $0.81 \pm 0.22$ \\
\hline $400-500$ & $8.0 \pm 4.1$ & $12.8 \pm 6.1$ & $55.0 \pm 18.9$ & $32.3 \pm 23.6$ & $9.0 \pm 0.6$ & $0.80 \pm 0.24$ \\
\hline
\end{tabular}

† Mean \pm standard deviation.

dition, the deeper sandy soil layers stored a higher proportion of the SOC than did the layers immediately below the top $100-\mathrm{cm}$ layer. In contrast, the storage in the loamy soils was more uniformly distributed.

\section{Land Use}

In the 0 - to $200-\mathrm{cm}$ layer, SOC stocks were significantly lower under the shrubland than those under either the cropland or the grassland at each depth (Fig. 4). However, there were no significant differences in the SOC stocks under cropland and grassland. In addition, at depths below $200 \mathrm{~cm}$, SOC stocks were not significantly different among the three land use types. The patterns of vertical distribution of SOC stocks were similar among the land uses. However, under cropland the distribution pattern was shallower, with more SOC in the surface layers (Fig. $4 \mathrm{~A}$ ), while under shrubland the distributional pattern was deeper, with more SOC in the deeper layers (Fig. 4C), and that under grassland was intermediate (Fig. 4B).

The 0 - to $100-\mathrm{cm}$ layers contained more SOC than the other $100-\mathrm{cm}$ layers within the $200-$ to $500-\mathrm{cm}$ depth. In the 0 - to $100-\mathrm{cm}$ layer, the SOC stocks under cropland, grassland, and shrubland were $2.64 \pm 0.67,2.50 \pm 0.69$, and $1.99 \pm 0.22$ $\mathrm{kg} \mathrm{m}^{-2}$, respectively. The corresponding values in the 0 - to 500 $\mathrm{cm}$ layer were $8.34 \pm 2.26,8.37 \pm 2.01$, and $7.26 \pm 1.00 \mathrm{~kg}$ $\mathrm{m}^{-2}$ (Fig. 4). The SOC stocks in the 0 - to $500-\mathrm{cm}$ layer were about 3.2, 3.4, and 3.6 times higher than those in the 0- to 100cm layer under cropland, grassland, and shrubland, respectively. The total mean SOC stocks in each layer between 100 and 500 $\mathrm{cm}$ represented about 54, 59, and 66\% of the amount of the SOC stock that was in the 0 - to $100-\mathrm{cm}$ layer under cropland, grassland, and shrubland, respectively. This indicates that a considerable amount of $\mathrm{OC}$ was stored in these deep soil layers.

\section{Topography}

The SOC stocks differed significantly $(P<0.01)$ between shaded and sunlit aspects only in the 200- to 300- and 300- to 400-cm soil layers (Fig. 5A). Also, there were significant effects

Table 3. Number and relative percentages of sites with a particular soil type under three land uses in the Lao Ye Man Qu watershed.

\begin{tabular}{lccc} 
Land use & Loamy soil & Sandy soil & Total \\
\hline Cropland & & & \\
$\quad$ Total $(n)$ & 11 & - & 11 \\
$\quad$ Proportion, $\%$ & 100 & - & 100 \\
Grassland & & - & 22 \\
$\quad$ Total $(n)$ & 22 & - & 100 \\
$\quad$ Proportion, $\%$ & 100 & & \\
Shrubland & & 13 & 40 \\
$\quad$ Total $(n)$ & 27 & 32 & 100 \\
$\quad$ Proportion, $\%$ & 68 & &
\end{tabular}


of slope position on the SOC stocks (Fig. 5B). The SOC stock was the least at the mid-slope position and the greatest on the upper slopes. However, more SOC was stored in the deeper soil layers below $100 \mathrm{~cm}$ at the mid-slope position than in those layers at either the upper or the lower slope positions.

\section{Factors Affecting Soil Organic Carbon Stocks at the Watershed Scale}

The Pearson correlation analysis indicated that SOC stock was most closely correlated with soil texture (Table 4). Clay and silt contents were positively correlated, and sand content was negatively correlated, with SOC stock. Correlations were generally higher in deeper soil layers than in the surface $(0-10 \mathrm{~cm})$ soil layer. There were significant and positive correlations between SOC stocks and SWC in all soil layers $(P<0.05)$, but in the 10 - to 20 -cm layer the significance was weaker). The correlations between SOC stock and soil $\mathrm{pH}$ fluctuated greatly with depth. The SOC stock was negatively correlated with slope gradient in all layers. However, SOC stock was very weakly correlated with altitude, and no significant correlations occurred for any of the soil layers.

\section{DISCUSSION}

\section{Sources of Variation in Soil Organic Carbon Distribution at the Watershed Scale}

Land use significantly influenced the levels of SOC to a depth of at least $200 \mathrm{~cm}$ (Fig. 4). Different land uses are usually associated with different types of vegetation that cause SOC levels to differ due to differences in plant productivity, quality, and turnover time (Wiesmeier et al., 2012). Cropland is usually assumed to have lower SOC contents than natural land use types such as grassland or shrubland. This is because the biomass is continually removed and soil disturbance in cropland can increase decomposition and losses due to erosion (Chen et al., 2007a; Deng et al., 2014). However, in this study, shrubland had significantly lower SOC stocks than either cropland or grassland in each layer to a depth of $200 \mathrm{~cm}$ (Fig. 4A). There are four possible reasons for these relatively low SOC stocks under shrubland.

1. Applying organic manure to cropland is a typical practice in China. The manure contains large amounts of organic matter, some of which is already in the form of liquid decomposition byproducts. Dissolved OC might be leached from the surface layer into deeper soil layers of the loamy soils. The depth to which leaching could occur would generally be dependent on the amount of $\begin{array}{llll}\text { Clay (\%) } & \text { Silt (\%) } & \text { Sand }(\%)\end{array}$
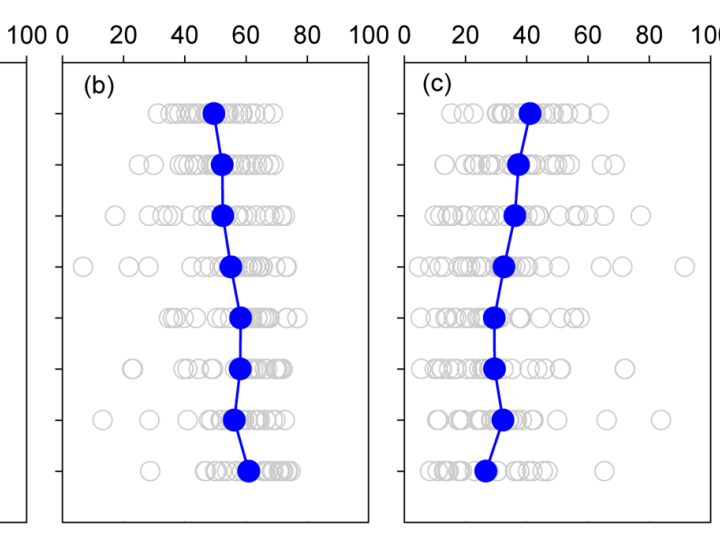

(e)
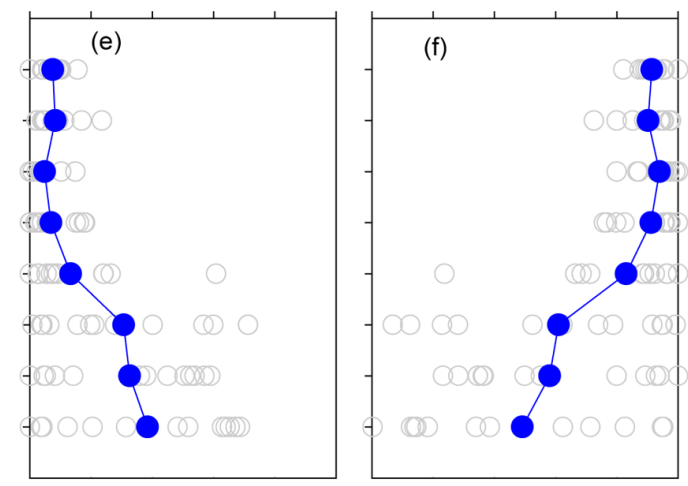

Fig. 2. Vertical distributions of clay $(<0.002 \mathrm{~mm})$, silt $(0.002-0.5 \mathrm{~mm})$, and sand $(0.5-1 \mathrm{~mm})$ for (A) the loamy soil $(n=27)$ and (B) the sandy soil $(n=13)$ under shrubland in the Lao Ye Man Qu watershed. The circles outlined in gray or filled with blue represent the measured values and their mean, respectively, for a sampled depth.

precipitation so that, apart from exceptionally wet years, it would be limited to the upper soil layers. It would also depend on the capacity of the OC to bind with the mineral soil and, hence, on soil texture.
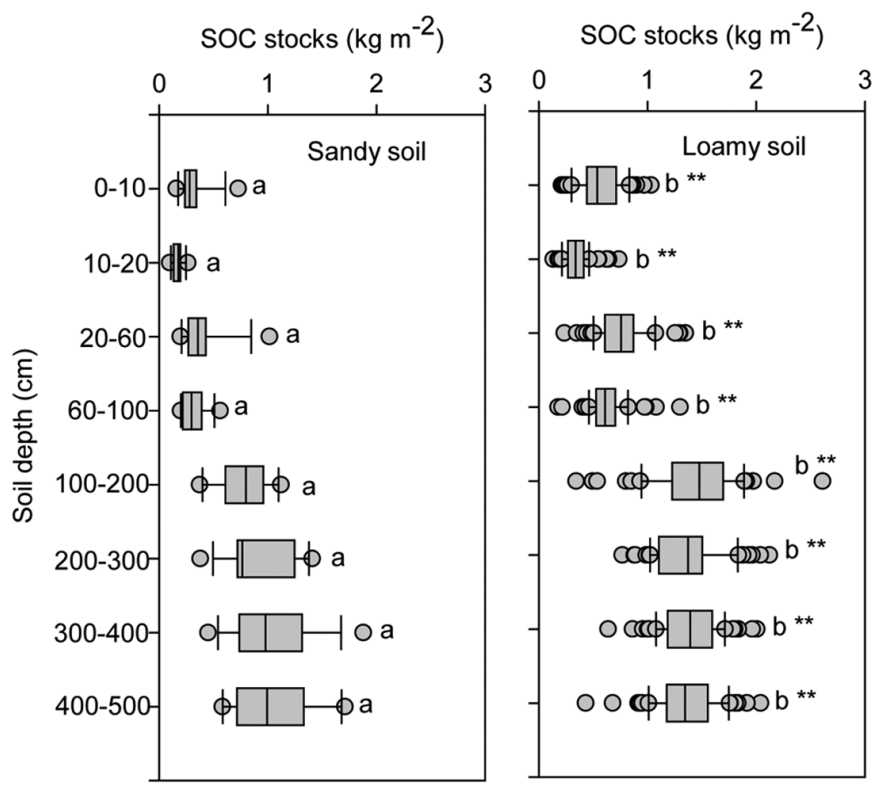

Fig. 3. The vertical distribution of soil organic C (SOC) stocks for the two soil types in the Lao Ye Man Qu watershed. Different lowercase letters indicate significant differences between the SOC stocks within the same layer in different soil types (least significant difference test: ${ }^{*} \boldsymbol{P}<0.05$; $* * P<0.01$ ). 
2. Grassland is characterized by extensive root systems (Tate and Ross, 1997), efficient accumulation of biomass via photosynthesis, longer growing seasons due to earlier and later seasonal growing periods, and the allocation of plant resources. This latter factor is related to the net primary production of grassland plants, which is probably more efficient than that of shrubs (Wang et al., 2015).

3. Shrubs, such as Korshinsk peashrub or other species listed in Table 1, require a longer time than grass to resume growing to recover from a winter without leaves (Wang et al., 2015).

4. The distribution of the land use types tends to be related to soil erosion and deposition of eroded sediments that would be associated with the translocation of SOC. Cropland has been restricted to more level ground at the tops of slopes, utilizing the undissected parts of the plateau surface, while land management practices protect the soil from erosion and thereby reduce SOC translocation. Grassland is more effective than shrubland in reducing surface erosion and is better than shrubs at enhancing deposition, thereby increasing the opportunities for SOC capture and retention.

A further possible reason for the low SOC stocks under shrubland is that both cropland and grassland sites had loamy soils. In contrast, only $68 \%$ of the shrubland sites had loamy soils and $32 \%$ had sandy soils. The heterogeneity of the soil textures played an important role in the variable distribution of SOC (Fig. 2). Coarser soils usually have relatively low degrees of vegetative surface cover, even with the formation of biological crusts, due to lower SWCs. Consequently, the coarser soil of the shrubland may have aggravated $\mathrm{C}$ losses for two reasons. First, the higher hydraulic conductivity of the sandy soil might lead to the leaching of dissolved OC below the depth of $100 \mathrm{~cm}$, especially in exceptionally wet years with the potential for greater rainwater recharge. Second, the reduced vegetation cover could lead to higher amounts of erosion. The significant influence of soil texture on SOC has also been reported in other studies (Jobbágy and Jackson, 2000; Wiesmeier et al., 2012; Zinn et al., 2005).

Topographical features such as slope position also significantly influenced the distribution of SOC at the watershed scale (Fig. 5). Schwanghart and Jarmer (2011) reported similar findings. The SOC stock was lowest at mid-slope and highest at upper slope positions, which was different from the results of Norton et al. (2003). There are three main reasons for these differences.
(A) Cropland SOC stocks $\left(\mathrm{kg} \mathrm{m}^{-2}\right)$

(B) Grassland

(C) Shrubland

SOC stocks $\left(\mathrm{kg} \mathrm{m}^{-2}\right)$

SOC stocks $\left(\mathrm{kg} \mathrm{m}^{-2}\right)$
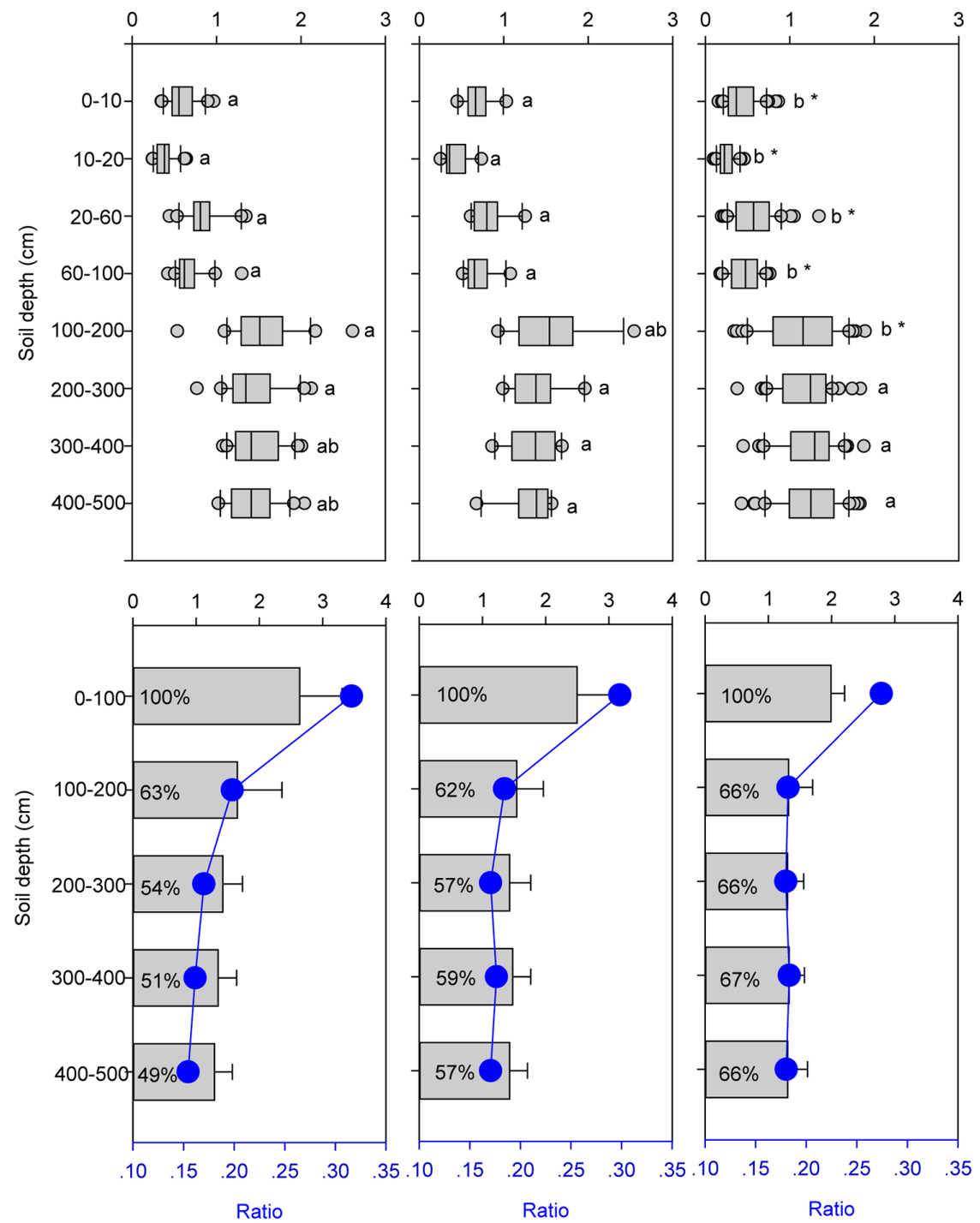

Fig. 4. Boxplots (upper graphs) of soil organic C (SOC) stocks in each layer within the $\mathbf{0}$ - to $500-\mathrm{cm}$ soil profiles under three land use types in the Lao Ye Man Qu watershed. Bar graphs (lower graphs) illustrate the SOC stock in each soil layer; percentages within the bars are the proportions of the soil stock in a particular $100-\mathrm{cm}$-thick layer to the soil stock in the 0 - to $100-\mathrm{cm}$ layer. Blue circles represent the ratio of the soil stock in a given $100-\mathrm{cm}$-thick layer to the total SOC stock in the 0 - to $500-\mathrm{cm}$ profile. Boxes with a lowercase letter in common indicate no significant difference in SOC stocks within the same soil layer under two different land uses (least significant difference test: $* P<0.05 ;{ }^{* * P}<0.01$ ).

1. As noted above, all the cropland sites were located at the tops of the slopes, which means that manure application may have contributed to the $\mathrm{C}$ stocks, especially within the 0 - to $100-\mathrm{cm}$ profile. In longterm experiments $(80 \mathrm{yr})$ at the Pendleton Agricultural Research Center in Oregon, where the annual precipitation is similar to that of the study watershed, the contribution of manure on SOC below a depth of $30 \mathrm{~cm}$ was also limited (Rasmussen and Parton, 1994; Ghimire et al., 2015).

2. The prevalence of sandy soils at mid-slope positions implies that more $\mathrm{C}$ can be leached preferentially into deep soil layers and possibly below the depth of $100 \mathrm{~cm}$, while lateral transfer processes of $\mathrm{C}$ are weak. 

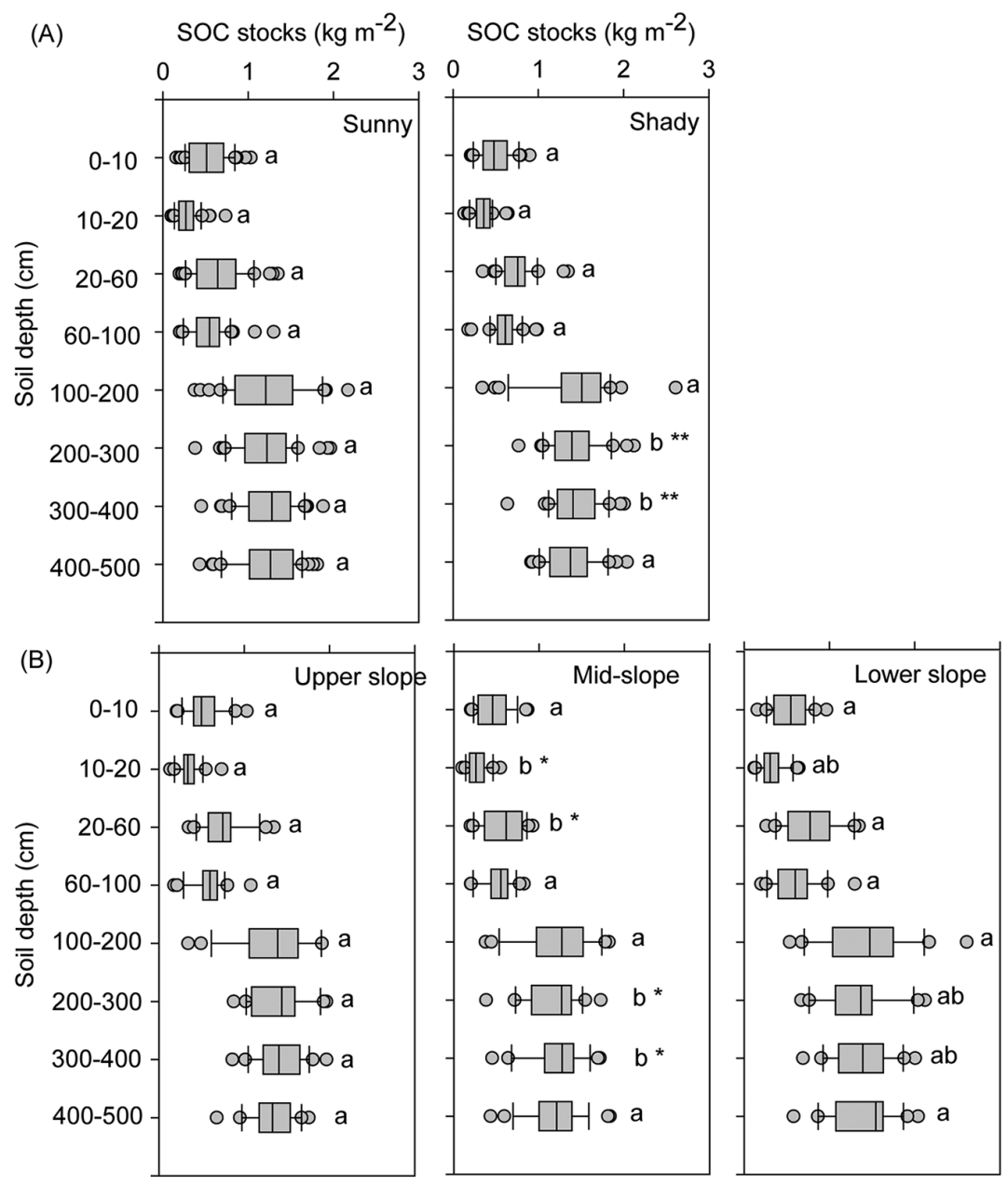

Fig. 5. Vertical distributions of soil organic C (SOC) stocks for different (A) slope aspects and (B) slope positions in the Lao Ye Man Qu watershed. Boxes with a lowercase letter in common indicate no significant difference in SOC stocks within the same soil layer with either different aspects or at two different positions (least significant difference test: ${ }^{* P}$ $<0.05 ; * * P<0.01$ )

3. The soil and hydrological processes among study areas around the world are different. For example, the soils of the study area of Norton et al. (2003) were derived from alluvial materials, and the related $\mathrm{C}$ processes were mainly driven by elevation, lithology, and vegetation. In contrast, the loessial soils in our study area were formed over aeolian deposits and deposition is ongoing, burying surface soils, while the main factors affecting $\mathrm{C}$ processes are water movement, soil texture, and land use.

The effects of slope aspect on SOC were generally weak in our study (Fig. 5A), perhaps due to changes in altitude that were relatively small $(75 \mathrm{~m})$. Generally, altitude affects the distribution of solar radiation and, hence, $\mathrm{C}$ cycling. The effects of altitude and slope aspect on SOC increases significantly across larger elevation ranges (Wang et al., 2002, 2009a).

\section{Depth Dependence of Soil Organic Carbon Stocks}

The SOC stocks decreased with depth under all land use types in all categories in the deeper soil layers $(100-500 \mathrm{~cm})$, which is clearly illustrated in Fig. 3 to 5. The decreasing trend in SOC stocks in the 0 - to 100 - $\mathrm{cm}$ layer in the present study was a natural phenomenon and in agreement with previous studies on the CLP (Han et al., 2010; Wei et al., 2010) and at other study sites with different vegetation (Omonode and Vyn, 2006). Little information about SOC below $100 \mathrm{~cm}$ is available for comparison. However, in our study, there was a consistent vertical trend in deep SOC under all land use types, whereby levels of SOC decreased relatively slowly as soil depth increased. This is suggestive of past inputs of OC that may have been similar and are now in more stable forms in the deeper layers because the input of new material to deep soil layers would be necessarily limited (Díaz-Hernández, 2010; Jobbágy and Jackson, 2000; Sommer et al., 2000).

The SOC stocks were dependent on depth (Fig. 4), which was highly affected by the distribution of land use types and associated plant root distributions, which were the main source of organic $\mathrm{C}$ within the soil layers either through their exudates or their decomposition (Liebig et al., 2005; Nepstad et al., 1994; Strand et al., 2008). Within the deep profiles, the vertical pattern of SOC depends to a large extent on the source of the loess, which was originally moved and deposited by wind (Pye, 1995). The occurrence of a layer of paleosol, which had significantly more SOC than the loessial layer (Wu et al., 2011), may affect the vertical distribution of deep SOC. The layered nature of the soil profile suggests that a more detailed study (e.g., finer sampling intervals) is required. It is known that in the study area, the paleosol could be found among the upper soil layers in the soil on the shady slope and among the deeper layers in the soil on the sunny slope. These different positions within the soil profiles were probably a product of the different rates of soil erosion caused by wind and/or water occurring on these slopes. The paleosols developed around 0.5 million yr ago.

Considerable amounts of SOC were stored in the deeper soil layers below a depth of $100 \mathrm{~cm}$. The reported storage of SOC on the CLP based only on measurements in the upper $100-\mathrm{cm}$ layer is thus severely underestimated because the SOC in the deeper soil layers was not included. Such a high proportion of OC stored in the deep layers deserves attention. Compared with other studies (Batjes, 1996; Sommer et al., 2000), the proportion of $\mathrm{OC}$ was higher in our study for the corresponding layers. Hence, the contribution of the SOC stored in the deep soils of the CLP and elsewhere around the world must clearly be included to obtain a more accurate global $\mathrm{C}$ budget. Studies that focus on regions with deep soils must be carefully planned and executed to correctly evaluate the global SOC pool.

It should be noted that the relative importance of SOC in surface and subsurface soil depends on the dynamic processes of 
Table 4. Pearson correlation analysis of soil organic $C$ stocks at eight depths with measured soil properties and environmental variables at 73 sites in the Lao Ye Man Qu watershed.

\begin{tabular}{|c|c|c|c|c|c|c|c|c|}
\hline \multirow[b]{2}{*}{ Variablet } & \multicolumn{8}{|c|}{ Pearson correlation coefficient } \\
\hline & 0-10 cm & $10-20 \mathrm{~cm}$ & $20-60 \mathrm{~cm}$ & $60-100 \mathrm{~cm}$ & $100-200 \mathrm{~cm}$ & $200-300 \mathrm{~cm}$ & $300-400 \mathrm{~cm}$ & $400-500 \mathrm{~cm}$ \\
\hline Land use & $0.389 * *$ & $0.497^{* *}$ & $0.459 * *$ & $0.467^{* *}$ & $0.370^{* *}$ & $0.338^{* *}$ & $0.333^{* *}$ & $0.270^{*}$ \\
\hline SA & -0.069 & 0.228 & 0.183 & 0.146 & 0.169 & $0.316^{* *}$ & $0.303^{* *}$ & 0.225 \\
\hline SP & 0.171 & 0.166 & $0.305^{* *}$ & 0.189 & 0.161 & $0.237^{*}$ & $0.238^{*}$ & $0.285^{*}$ \\
\hline SG & $-0.231^{*}$ & -0.14 & $-0.289^{*}$ & $-0.348^{* *}$ & -0.212 & -0.224 & $-0.237^{*}$ & -0.225 \\
\hline Altitude & -0.117 & 0.037 & 0.052 & 0.021 & -0.007 & 0.091 & 0.028 & -0.063 \\
\hline $\mathrm{pH}$ & 0.1 & 0.116 & $0.269^{*}$ & 0.126 & 0.113 & $0.257^{*}$ & 0.221 & $0.386^{* *}$ \\
\hline SWC & $0.473^{* *}$ & $0.290^{*}$ & $0.510^{* *}$ & $0.595^{* *}$ & $0.470^{* *}$ & $0.440^{* *}$ & $0.357^{* *}$ & $0.457^{* *}$ \\
\hline Clay & $0.324^{* *}$ & $0.475^{* *}$ & $0.512^{* *}$ & $0.546^{* *}$ & $0.463^{* *}$ & $0.406^{* *}$ & 0.229 & $0.299 *$ \\
\hline Silt & $0.324^{* *}$ & $0.490^{* *}$ & $0.543^{* *}$ & $0.633^{* *}$ & $0.515^{* *}$ & $0.569^{* *}$ & $0.478^{* *}$ & $0.418^{* *}$ \\
\hline Sand & $-0.326^{* *}$ & $-0.492^{* *}$ & $-0.544^{* *}$ & $-0.627^{* *}$ & $-0.515^{* *}$ & $-0.551^{* *}$ & $-0.445^{* *}$ & $-0.413^{* *}$ \\
\hline
\end{tabular}

* Significant correlations at the 0.05 probability level (2-tailed).

** Significant correlations at the 0.01 probability level (2-tailed).

+ SA, slope aspect; SP, slope position; SG, slope gradient; SWC, soil water content

decomposition and synthesis that occur at different rates (Dean et al., 2012; Poeplau et al., 2011). Deep SOC is more stable over time because it is not directly subject to the short-term effects of weather and soil disturbance (Kautz et al., 2013; Mendez-Millan et al., 2012). Rumpel et al. (2002) reported that $50 \%$ of the SOC stored in the deeper soil layers had a higher residence time than the SOC stored in the upper layers where microbial activity was higher. Radiocarbon dating has indicated that SOC in deeper soil layers has high mean residence times of up to several thousand years; the deeper soil contained higher concentrations of stable C compounds that have longer residence times (Rumpel and Kögel-Knabner, 2011). The high amounts of SOC in deep layers on the CLP may indicate that these layers were once topsoils onto which more loess was deposited (Pye, 1995). This is more pertinent to the CLP where buried soils or paleosols occur (Zhao et al., 2012) that may contain ancient and relatively more stable forms of SOC. Paleosols were also more likely formed when SOC levels were higher under climatic conditions favorable for the development of a true soil (loessial soils are characteristically undeveloped) (Wu et al., 2011). Deep SOC probably comes from the most stable components of organic matter; very little unstable $\mathrm{C}$ remains after passage of the time involved in creating deep soils (Rumpel and Kögel-Knabner, 2011).

The SOC stocks did not differ significantly between grassland and cropland (Fig. 4). Native grasses renew their roots completely within a few years, so the contribution of root material may not be as great as that from the annual turnover in cropland. In the shrubland, Korshinsk peashrub usually has a deep root system and would deposit $\mathrm{C}$ throughout a thicker soil layer with time (Cheng et al., 2009; Wang et al., 2015), potentially resulting in much higher total SOC stocks within the entire profile than under the other land uses.

Understanding the vertical distributions of SOC stocks to deeper depths and its related factors are also important for evaluating climate change (Jobbágy and Jackson, 2000). For example, scenarios of climate change with different patterns of vegetation and climatic conditions predict changes in root allocation, including belowground biomass and root exudates, which would lead to large changes in the vertical distribution of SOC. Increased inputs of SOC derived from roots or their exudates into deep soils may, to some extent, alleviate the increases in atmospheric $\mathrm{CO}_{2}$, especially under the auspices of the Grainfor-Green program that has been implemented at a regional scale (Lu et al., 2012). This program plays an important role in C cycling by virtue of its ongoing changes in land use patterns and, potentially, local climatic conditions (Deng et al., 2014).

\section{CONCLUSIONS}

We measured SOC stocks and various soil properties to a depth of $500 \mathrm{~cm}$ as well as topographic features at the watershed scale on the CLP. Soil OC stocks were significantly lower under shrubland than under either cropland or grassland in the 0 - to 200-cm soil layer, although the overall vertical distributions of SOC stocks were similar among the three land use types. Soil OC stocks were about 3.2, 3.4, and 3.6 times greater in the 0 - to $500-\mathrm{cm}$ soil layer than in the 0 - to $100-\mathrm{cm}$ layer under cropland, grassland, and shrubland, respectively. Soil OC stocks were significantly higher in loamy than in sandy soils in each $100-\mathrm{cm}-$ thick soil layer $(P<0.01)$. Stocks were significantly lower at mid-slope than at upper and lower slope positions $(P<0.01)$ but were similar on slopes with shaded and sunlit aspects. Soil OC stocks were significantly correlated with land use, soil texture, and SWC. The correlation with topographic properties varied with the soil layer. Correlations with soil $\mathrm{pH}$ generally increased with soil depth. A considerable amount of SOC was stored in deep soils to a depth of at least $500 \mathrm{~cm}$, which was strongly affected by land use, soil texture, and slope position. Deep SOC was time and depth dependent. This information is important for evaluating $\mathrm{C}$ fluxes, estimating $\mathrm{C}$ stocks, and mediating $\mathrm{C}$ cycling in regions with deep soils around the world.

\section{ACKNOWLEDGMENTS}

This research was supported by the National Natural Science Foundation of China (no. 41471189, 41530854, and 41101204), the New Star Foundation on Shaanxi Province Youth Science and Technology (2013KJXX-09), the CAS "Light of West China" Program, and the Youth Innovation Promotion Association CAS. Special thanks also go 
to Dr. William Blackhall and Dr. David Warrington for their zealous help in improving the manuscript.

\section{REFERENCES}

Alexander, E.B. 1980. Bulk densities of California soils in relation to other soil properties. Soil Sci. Soc. Am. J. 44:689-692. doi:10.2136/ sssaj1980.03615995004400040005x

Balland, V., J.A.P. Pollacco, and P.A. Arp. 2008. Modeling soil hydraulic properties for a wide range of soil conditions. Ecol. Modell. 219:300-316. doi:10.1016/j.ecolmodel.2008.07.009

Batjes, N.H. 1996. Total carbon and nitrogen in the soils of the world. Eur. J. Soil Sci. 47:151-163. doi:10.1111/j.1365-2389.1996.tb01386.x

Booker, K., L. Huntsinger, J.W. Bartolome, N.F. Sayre, and W. Stewart. 2013. What can ecological science tell us about opportunities for carbon sequestration on arid rangelands in the United States? Global Environ. Change 23:240-251. doi:10.1016/j.gloenvcha.2012.10.001

Burnham, J.H., and R.S. Sletten. 2010. Spatial distribution of soil organic carbon in northwest Greenland and underestimates of high arctic carbon stores. Global Biogeochem. Cycles 24:GB3012.

Chen, L., J. Gong, B. Fu, Z. Huang, Y. Huang, and L. Gui. 2007a. Effect of land use conversion on soil organic carbon sequestration in the loess hilly area, Loess Plateau of China. Ecol. Res. 22:641-648. doi:10.1007/s11284-006-0065-1

Chen, L., W. Wei, B. Fu, and Y. Lü. 2007b. Soil and water conservation on the Loess Plateau in China: Review and perspective. Prog. Phys. Geogr. 31:389-403. doi:10.1177/0309133307081290

Cheng, X., M. Huang, M. Shao, and D.N. Warrington. 2009. A comparison of fine root distribution and water consumption of mature Caragana korshinkii Kom grown in two soils in a semiarid region, China. Plant Soil 315:149-161. doi:10.1007/s11104-008-9739-5

Davidson, E., P.A. Lefebvre, P.M. Brando, D.M. Ray, S.E. Trumbore, L.A. Solorzano, et al. 2011. Carbon inputs and water uptake in deep soils of an eastern Amazon forest. For. Sci. 57:51-58.

Davidson, E.A., and I.A. Janssens. 2006. Temperature sensitivity of soil carbon decomposition and feedbacks to climate change. Nature 440:165-173. doi: $10.1038 /$ nature 04514

Dean, C., S.H. Roxburgh, R.J. Harper, D.J. Eldridge, I.W. Watson, and G.W. Wardell-Johnson. 2012. Accounting for space and time in soil carbon dynamics in timbered rangelands. Ecol. Eng. 38:51-64. doi:10.1016/j. ecoleng.2011.10.008

Deng, L., G. Liu, and Z. Shangguan. 2014. Land-use conversion and changing soil carbon stocks in China's 'Grain-for-Green' program: A synthesis. Global Change Biol. 20:3544-3556. doi:10.1111/gcb.12508

Desjardins, R., W. Smith, B. Grant, C. Campbell, and R. Riznek. 2005. Management strategies to sequester carbon in agricultural soils and to mitigate greenhouse gas emissions. Clim. Change 70:283-297. doi:10.1007/s10584-005-5951-y

Díaz-Hernández, J.L. 2010. Is soil carbon storage underestimated? Chemosphere 80:346-349. doi:10.1016/j.chemosphere.2010.04.038

Dilling, L., and E. Failey. 2013. Managing carbon in a multiple use world: The implications of land-use decision context for carbon management. Global Environ. Change 23:291-300. doi:10.1016/j.gloenvcha.2012.10.012

Dou, X., Q. Deng, M. Li, W. Wang, Q.Zhang, and X. Cheng. 2013. Reforestation of Pinus massoniana alters soil organic carbon and nitrogen dynamics in eroded soil in South China. Ecol. Eng. 52:154-160. doi:10.1016/j. ecoleng.2012.12.099

Fontaine, S., S. Barot, P. Barre, N. Bdioui, B. Mary, and C. Rumpel. 2007. Stability of organic carbon in deep soil layers controlled by fresh carbon supply. Nature 450:277-280. doi:10.1038/nature06275

Ghimire, R., M. Stephen, and R. Karl. 2015. Long-term crop residue and nitrogen management effects on soil profile carbon and nitrogen in wheatfallow systems. Agron. J. 107:2230-2240.

Grimm, R., T. Behrens, M. Märker, and H. Elsenbeer. 2008. Soil organic carbon concentrations and stocks on Barro Colorado Island: Digital soil mapping using Random Forests analysis. Geoderma 146:102-113. doi:10.1016/j. geoderma.2008.05.008

Han, F., W. Hu, J. Zheng, F. Du, and X. Zhang. 2010. Estimating soil organic carbon storage and distribution in a catchment of Loess Plateau, China. Geoderma 154:261-266. doi:10.1016/j.geoderma.2009.10.011

Harper, R.J., and M. Tibbett. 2013. The hidden organic carbon in deep mineral soils. Plant Soil 368:641-648. doi:10.1007/s11104-013-1600-9
Harrison, R.B., P.W. Footen, and B.D. Strahm. 2011. Deep soil horizons: Contribution and importance to soil carbon pools and in assessing wholeecosystem response to management and global change. For. Sci. 57:67-76.

Hergoualc'h, K., and L.V. Verchot. 2011. Stocks and fluxes of carbon associated with land use change in Southeast Asian tropical peatlands: A review. Global Biogeochem. Cycles 25:GB2001. doi:10.1029/2009GB003718

Hou, R., Z. Ouyang, Y. Li, D.D. Tyler, F. Li, and G.V. Wilson. 2012. Effects of tillage and residue management on soil organic carbon and total nitrogen in the North China Plain. Soil Sci. Soc. Am. J. 76:230-240. doi:10.2136/ sssaj2011.0107

Huo, L., Z. Chen, Y. Zou, X. Lu, J. Guo, and X. Tang. 2013. Effect of Zoige alpine wetland degradation on the density and fractions of soil organic carbon. Ecol. Eng. 51:287-295. doi:10.1016/j.ecoleng.2012.12.020

Jeong, J., C. Kim, K.-S. Lee, N.S. Bolan, and R. Naidu. 2013. Carbon storage and soil $\mathrm{CO}_{2}$ efflux rates at varying degrees of damage from pine wilt disease in red pine stands. Sci. Total Environ. 465:273-278. doi:10.1016/j. scitotenv.2012.11.080

Jimenez, J.J., R. Lal, R.O. Russo, and H.A. Lablanc. 2008. The soil organic carbon in particle-size separates under different regrowth forest stands of north eastern Costa Rica. Ecol. Eng. 34:300-310. doi:10.1016/j. ecoleng.2008.07.001

Jobbágy, E.G., and R.B. Jackson. 2000. The vertical distribution of soil organic carbon and its relation to climate and vegetation. Ecol. Appl. 10:423-436. doi:10.1890/1051-0761(2000)010[0423:TVDOSO]2.0.CO;2

Kautz, T., W. Amelung, F. Ewert, T. Gaiser, R. Horn, R. Jahn, et al. 2013. Nutrient acquisition from arable subsoils in temperate climates: A review. Soil Biol. Biochem. 57:1003-1022. doi:10.1016/j.soilbio.2012.09.014

Lal, R. 2004a. Soil carbon sequestration to mitigate climate change. Geoderma 123:1-22. doi:10.1016/j.geoderma.2004.01.032

Lal, R. 2004b. Soil carbon sequestration impacts on global climate change and food security. Science 304:1623-1627. doi:10.1126/science.1097396

Lal, R., R.F. Follett, B.A. Stewart, and J.M. Kimble. 2007. Soil carbon sequestration to mitigate climate change and advance food security. Soil Sci. 172:943-956. doi:10.1097/ss.0b013e31815cc498

Liebig, M.A., H.A. Johnson, J.D. Hanson, and A.B. Frank. 2005. Soil carbon under switchgrass stands and cultivated cropland. Biomass Bioenergy 28:347-354. doi:10.1016/j.biombioe.2004.11.004

Liu, Z., M. Shao, and Y. Wang. 2011. Effect of environmental factors on regional soil organic carbon stocks across the Loess Plateau region, China. Agric. Ecosyst. Environ. 142:184-194. doi:10.1016/j.agee.2011.05.002

Lu, Y., B. Fu, X. Feng, Y. Zeng, Y. Liu, R. Chang, et al. 2012. A policy-driven large scale ecological restoration: Quantifying ecosystem services changes in the Loess Plateau of China. PLoS ONE 7:e31782. doi:10.1371/journal. pone.0031782

Manrique, L.A., and C.A. Jones. 1991. Bulk density of soils in relation to soil physical and chemical properties. Soil Sci. Soc. Am. J. 55:476-481. doi:10.2136/sssaj1991.03615995005500020030x

McLean, E.O. 1982. Soil pH and lime requirement. In: A.L. Page et al., editors, Methods of soil analysis. Part 2. 2nd ed. Agron. Monogr. 9. ASA and SSSA, Madison, WI. p. 199-224. doi:10.2134/agronmonogr9.2.2ed.c12

Mendez-Millan, M., M.F. Dignac, C. Rumpel, D.P. Rasse, G. Bardoux, and S. Derenne. 2012. Contribution of maize root derived $C$ to soil organic carbon throughout an agricultural soil profile assessed by compound specific ${ }^{13} \mathrm{C}$ analysis. Org. Geochem. 42:1502-1511. doi:10.1016/j. orggeochem.2011.02.008

Nelson, D.W., and L.E. Sommers. 1982. Total carbon, organic carbon, and organic matter. In: A.L. Page et al., editors, Methods of soil analysis. Part 2. 2nd ed. Agron. Monogr. 9. ASA and SSSA, Madison, WI. p. 539-579. doi:10.2134/agronmonogr9.2.2ed.c29

Nepstad, D.C., C.R. Decarvalho, E.A. Davidson, P.H. Jipp, P.A. Lefebvre, G.H. Negreiros, et al. 1994. The role of deep roots in the hydrological and carbon cycles of Amazonian forests and pastures. Nature 372:666-669. doi: $10.1038 / 372666 \mathrm{a} 0$

Norton, J.B., J.A. Sandor, and C.S. White. 2003. Hillslope soils and organic matter dynamics within a Native American agroecosystem on the Colorado Plateau. Soil Sci. Soc. Am. J. 67:225-234. doi:10.2136/sssaj2003.2250

Omonode, R.A., and T.J. Vyn. 2006. Vertical distribution of soil organic carbon and nitrogen under warm-season native grasses relative to croplands in west-central Indiana, USA. Agric. Ecosyst. Environ. 117:159-170. doi:10.1016/j.agee.2006.03.031 
Poeplau, C., A. Don, L. Vesterdal, J. Leifeld, B. Van Wesemael, J. Schumacher, and A. Gensior. 2011. Temporal dynamics of soil organic carbon after landuse change in the temperate zone: Carbon response functions as a model approach. Global Change Biol. 17:2415-2427. doi:10.1111/j.13652486.2011.02408.x

Pye, K. 1995. The nature, origin and accumulation of loess. Quat. Sci. Rev. 14:653-667. doi:10.1016/0277-3791(95)00047-X

Rasmussen, P.E., and W.J. Parton. 1994. Long-term effects of residue management in wheat-fallow: I. Inputs, yield, and soil organic matter. Soil Sci. Soc. Am. J. 58:523-530. doi:10.2136/sssaj1994.03615995005800020039x

Rumpel, C., and I. Kögel-Knabner. 2011. Deep soil organic matter: A key but poorly understood component of terrestrial C cycle. Plant Soil 338:143158. doi:10.1007/s11104-010-0391-5

Rumpel, C., I. Kogel-Knabner, and F. Bruhn. 2002. Vertical distribution, age, and chemical composition of organic carbon in two forest soils of different pedogenesis. Org. Geochem. 33:1131-1142. doi:10.1016/S01466380(02)00088-8

Schwanghart, W., and T. Jarmer. 2011. Linking spatial patterns of soil organic carbon to topography: A case study from south-eastern Spain. Geomorphology 126:252-263. doi:10.1016/j.geomorph.2010.11.008

Shi, S., W. Zhang, P. Zhang, Y. Yu, and F. Ding. 2013. A synthesis of change in deep soil organic carbon stores with afforestation of agricultural soils. For. Ecol. Manage. 296:53-63. doi:10.1016/j.foreco.2013.01.026

Sommer, R., M. Denich, and P.L.G. Vlek. 2000. Carbon storage and root penetration in deep soils under small-farmer land-use systems in the eastern Amazon region, Brazil. Plant Soil 219:231-241. doi:10.1023/A:1004772301158

Strand, A.E., S.G. Pritchard, M.L. McCormack, M.A. Davis, and R. Oren. 2008. Irreconcilable differences: Fine-root life spans and soil carbon persistence. Science 319:456-458. doi:10.1126/science.1151382

Tate, K.R., and D.J. Ross. 1997. Elevated $\mathrm{CO}_{2}$ and moisture effects on soil carbon storage and cycling in temperate grasslands. Global Change Biol. 3:225-235. doi:10.1046/j.1365-2486.1997.00094.x

Tian, H., J. Melillo, C. Lu, D. Kicklighter, M. Liu, W. Ren, et al. 2011. China's terrestrial carbon balance: Contributions from multiple global change factors. Global Biogeochem. Cycles 25:GB1007. doi:10.1029/2010GB003838

Tornquist, C.G., E. Giasson, J. Mielniczuk, C.E.P. Cerri, and M. Bernoux. 2009. Soil organic carbon stocks of Rio Grande do Sul, Brazil. Soil Sci. Soc. Am. J. 73:975-982. doi:10.2136/sssaj2008.0112

Van Minnen, J., K. Klein Goldewijk, E. Stehfest, B. Eickhout, G. van Drecht, and R. Leemans. 2009. The importance of three centuries of land-use change for the global and regional terrestrial carbon cycle. Clim. Change 97:123144. doi:10.1007/s10584-009-9596-0

Wang, H., D. Guan, R. Zhang, Y. Chen, Y. Hu, and L. Xiao. 2014a. Soil aggregates and organic carbon affected by the land use change from rice paddy to vegetable field. Ecol. Eng. 70:206-211. doi:10.1016/j. ecoleng.2014.05.027

Wang, H., C.A.S. Hall, J.D. Cornell, and M.H.P. Hall. 2002. Spatial dependence and the relationship of soil organic carbon and soil moisture in the
Luquillo Experimental Forest, Puerto Rico. Landscape Ecol. 17:671-684. doi:10.1023/A:1022962116313

Wang, S., H. Tian, J. Liu, and S. Pan. 2003. Pattern and change of soil organic carbon storage in China: 1960s-1980s. Tellus B 55:416-427. doi:10.1034/j.1600-0889.2003.00039.x

Wang, Y., B. Fu, Y. Lü, C. Song, and Y. Luan. 2010a. Local-scale spatial variability of soil organic carbon and its stock in the hilly area of the Loess Plateau, China. Quat. Res. 73:70-76. doi:10.1016/j.yqres.2008.11.006

Wang, Y., Y. Li, X. Ye, Y. Chu, and X. Wang. 2010b. Profile storage of organic/ inorganic carbon in soil: From forest to desert. Sci. Total Environ. 408:1925-1931. doi:10.1016/j.scitotenv.2010.01.015

Wang, Y., M. Shao, and Z. Liu. 2013. Vertical distribution and influencing factors of soil water content within 21-m profile on the Chinese Loess Plateau. Geoderma 193-194:300-310. doi:10.1016/j.geoderma.2012.10.011

Wang, Y., M. Shao, Z. Liu, and C. Zhang. 2014b. Prediction of bulk density of soils in the Loess Plateau region of China. Surv. Geophys. 35:395-413. doi:10.1007/s10712-013-9249-8

Wang, Y.-Q., X.-C. Zhang, J.-L. Zhang, and S.-J. Li. 2009a. Spatial variability of soil organic carbon in a watershed on the Loess Plateau. Pedosphere 19:486-495. doi:10.1016/S1002-0160(09)60141-7

Wang, Y., M. Shao, C. Zhang, X. Han, T. Mao, and X. Jia. 2015. Choosing an optimal land-use pattern for restoring eco-environments in a semiarid region of the Chinese Loess Plateau. Ecol. Eng. 74:213-222. doi:10.1016/j. ecoleng.2014.10.001

Wang, Z.Q., B.Y. Liu, G. Liu, and Y.X. Zhang. 2009b. Soil water depletion depth by planted vegetation on the Loess Plateau. Sci. China, Ser. D 52:835-842. doi:10.1007/s11430-009-0087-y

Wei, X., M. Shao, X. Fu, and R. Horton. 2010. Changes in soil organic carbon and total nitrogen after 28 years grassland afforestation: Effects of tree species, slope position, and soil order. Plant Soil 331:165-179. doi:10.1007/s11104-009-0243-3

Wiesmeier, M., P. Sporlein, U. Geuss, E. Hangen, S. Haug, A. Reischl, et al. 2012. Soil organic carbon stocks in southeast Germany (Bavaria) as affected by land use, soil type and sampling depth. Global Change Biol. 18:22332245. doi:10.1111/j.1365-2486.2012.02699.x

Wu, H., Z. Guo, and C. Peng. 2003. Land use induced changes of organic carbon storage in soils of China. Global Change Biol. 9:305-315. doi:10.1046/ j.1365-2486.2003.00590.x

Wu, T., Y. Wang, J. Lv, and B. Zhang. 2011. Soil water characteristics of Middle Pleistocene paleosol layers on the Loess Plateau. Afr. J. Biotechnol. 10:10856-10863. doi:10.5897/AJB11.1927

Zhao, J., T. Long, C. Wang, and Y. Zhang. 2012. How the Quaternary climatic change affects present hydrogeological system on the Chinese Loess Plateau: A case study into vertical variation of permeability of the loess-palaeosol sequence. Catena 92:179-185. doi:10.1016/j.catena.2011.12.009

Zinn, Y.L., R. Lal, and D.V.S. Resck. 2005. Texture and organic carbon relations described by a profile pedotransfer function for Brazilian Cerrado soils. Geoderma 127:168-173. doi:10.1016/j.geoderma.2005.02.010 